\title{
Effect of 4-coumaric and 3,4-dihydroxybenzoic acid on oxidative DNA damage in rat colonic mucosa
}

\author{
Francesco Guglielmi*, Cristina Luceri, Lisa Giovannelli, Piero Dolara and Maura Lodovici \\ Department of Pharmacology, University of Florence, viale Pieraccini 6, 50139, Florence, Italy
}

(Received 7 May 2002 - Revised 3 December 2002 - Accepted 19 January 2003)

\begin{abstract}
The effect of 4-coumaric and 3,4-dihydroxybenzoic (protocatechuic) acid on the basal oxidative DNA damage of rat colonic mucosa in vivo was studied, relative to vitamin E. F344 rats were treated with 4-coumaric or protocatechuic acid mixed in the diet $(25$ or $50 \mathrm{mg} / \mathrm{kg}$ for 2 weeks). It was observed that 4-coumaric acid $(50 \mathrm{mg} / \mathrm{kg})$ significantly decreased the basal level of the oxidative damage assessed as 8-OH-2'-deoxyguanosine levels in DNA and by the comet assay. Moreover, it was found that vitamin E $(10 \mathrm{mg} / \mathrm{kg})$ had no effect on colonic mucosa oxidation damage, whereas at a higher dose $(55 \mathrm{mg} / \mathrm{kg})$ it actually enhanced oxidative stress. The effect of 4-coumaric acid $(50 \mathrm{mg} / \mathrm{kg})$ on the expression of some glutathione-related enzymes (glutathione-S-transferase (GST)-P, GST-M2, GST-M1, $\gamma$-glutamylcysteine synthetase, glutathione peroxidase (GSPX)1 and GSPX4) was also investigated at the level of the colonic mucosa. Only the expression of GST-M2 was significantly induced by 4-coumaric acid, while protocatechuic acid was inactive. The data suggest that 4-coumaric acid acts as an antioxidant in the colonic mucosa in vivo.
\end{abstract}

Oxidative DNA damage: 3,4-Dihydroxybenzoic acid: 4-Coumaric acid: Vitamin E: Glutathione

The so-called 'Mediterranean diet' protects against the risk of some types of cancer and cardiovascular diseases (Rimm et al. 1996; Willet, 2000). Its typical constituents are fruits, vegetables, vegetable oils and wine, containing several polyphenols, which are a broad class of natural compounds. Polyphenols have been extensively studied and are reported to possess several biological activities. Considering that their distribution is ubiquitous among plants and that human consumers ingest considerable quantities of these compounds, numerous studies have focused on their anti-mutagenic effects (Brown, 1980) and on their chemopreventive and anti-carcinogenic activities (Stich et al. 1983; Steel et al. 2000). Some authors have also documented the protective effect of phenols and phenolic extracts against oxygen radicals, generated by aerobic metabolism and by exposure to various xenobiotics (Havsteen, 1983; Hertog et al. 1993; Owen et al. 2000). Moreover, polyphenols have been shown to inhibit a wide range of enzymes such as phosphodiesterase and ATPases (Brown, 1980) and to enhance the production of glutathione (GSH) and GSH-related enzymes (Fiander \& Schneider, 2000; Steel et al. 2000).
In our laboratory it was recently demonstrated that polyphenolic compounds extracted from red wine and black tea provide protection against chemically-induced oxidative DNA damage in rat liver and intestine and also against azoxymethane-induced colon carcinogenesis (Caderni et al. 2000; Giovannelli et al. 2000; Lodovici et al. 2000).

Among the dietary polyphenols, 4-coumaric acid and 3,4-dihydroxybenzoic (protocatechuic) acid are widely distributed in many foods, the main sources of 4-coumaric acid being wine and tea $(1-24 \mathrm{mg} / \mathrm{l})$, spinach, Brussels sprouts and cereal brans $(2-60 \mathrm{mg} / \mathrm{kg})$, apples and berries (69-1 $700 \mathrm{mg} / \mathrm{kg}$ ) (Stich, 1991; Clifford, 2000).

Protocatechuic acid is a constituent of lignin and thus is universal in the Angiosperm plants, being found mainly in wine, green and black tea (up to $20 \mathrm{mg} / \mathrm{l}$ ), lettuce (200-4000 mg/kg), food spices and berries (3-189 mg/ kg) (Stich, 1991; Tomàs-Barberan \& Clifford, 2000).

Recently, it was demonstrated that protocatechuic acid, possessing two $o$-hydroxyl groups, exerts its antioxidant activity in vitro essentially by interaction with ferrous $\mathrm{Fe}$ while 4-coumaric acid is a radical scavenger and has no affinity for Fe in vitro (Lodovici et al. 2001).

\footnotetext{
Abbreviations: GSH, glutathione; GSPX, glutathione peroxidase; GST, glutathione-S-transferase; 8-OHdG, 8-OH-2'-deoxyguanosine; PCR, polymerase chain reaction.

*Corresponding author: Dr Francesco Guglielmi, fax +39055 4271280, email francesco.guglielmi@unifi.it
} 
Since oxidation damage is possibly an important mechanism mediating pathological inflammatory processes at the level of the intestinal wall, it was decided to evaluate the effect of 4-coumaric and protocatechuic acid on basal oxidative DNA damage in the rat colon, comparing it with the activity of an efficient free radical scavenger, $\alpha$-tocopherol (Rimm et al. 1993).

Since Tomàs-Barberan \& Clifford (2000) and Clifford (2000) reported a daily dietary intake up to $1 \mathrm{~g}$ for total cinnamates and hydroxybenzoic acid derivatives, corresponding to about $15 \mathrm{mg} / \mathrm{kg}$ per d in man, rats were fed with $50 \mathrm{mg}$ of these two phenols $/ \mathrm{kg}$, for a period of $15 \mathrm{~d}$.

The mRNA levels of different isoforms of glutathionetransferase (GST), glutathione peroxidase (GSPX) and $\gamma$-glutamylcysteine synthetase were also analysed.

\section{Materials and methods}

\section{Chemicals and diet}

Protocatechuic acid and 4-coumaric acid were obtained from Sigma-Aldrich (Milan, Italy); vitamin E (d, L- $\alpha$-tocopheryl acetate) from Bracco S.p.A (Milan, Italy); nuclease $\mathrm{P} 1$, alkaline phosphatase, RNAse, proteinase $\mathrm{K}$ and $10 \times$ random examers and primers, designed on the basis of the sequences reported by the UNIGENE database for the rat (Table 1), were purchased from Roche Diagnostic S.p.A (Milan, Italy). Trizol and reverse transcriptase superscript II were purchased from Life Technologies (San Giuliano Milanese, Milan, Italy), and Taq polymerase was obtained from Advanced Biotechnologies Ltd (Epsom, UK).

The standard laboratory chow was purchased from Harlan Teklad (Milan, Italy). The 2018 Teklad Global Protein Rodent Diet contained (g/kg): water, 120; protein, 185; fat, 55; fibre, 45; ash, 60; minerals, 0.13 (containing $50 \mathrm{mg}$ ferrous $\mathrm{Fe} / \mathrm{kg}$ and $44 \mathrm{mg} \mathrm{Mn} / \mathrm{kg}$ ); vitamin mix, 0.52 (containing $81 \mathrm{mg}$ vitamin $\mathrm{E} / \mathrm{kg}$ ).

\section{Animals}

Male F344 rats (about $120 \mathrm{~g}$ ) were obtained from Nossan (Corezzana, Milan, Italy). Rats were randomly divided into six groups and fed the experimental diets as described later. Animals were maintained at controlled temperature $\left(24 \pm 2^{\circ} \mathrm{C}\right)$ and humidity $(50 \%)$ with a $12 \mathrm{~h}$ light-dark cycle. During the experiments the weight and health of the rats were closely monitored. All the procedures adopted were carried out as stated in the European Union Regulations on the Care and Use of Laboratory Animals (European Community, 1986).

\section{Dietary treatments}

Protocatechuic acid and 4-coumaric acid were administered by mixing them with the standard diet. Vitamin $\mathrm{E}$ was mixed in the diet to a final dosage of 10 and $55 \mathrm{mg} / \mathrm{kg}$ animal (taking into account that the vitamin $\mathrm{E}$ content in the standard laboratory chow was $81 \mathrm{mg} / \mathrm{kg}$ ). The experimental groups included: (A) controls who received a standard laboratory chow ( $n$ 15); (B) rats treated with protocatechuic acid $(50 \mathrm{mg} / \mathrm{kg}, n 10)$; (C) rats treated with 4-coumaric acid (25 mg/kg, $n$ 10); (D) rats treated with 4coumaric acid $(50 \mathrm{mg} / \mathrm{kg}, n$ 10); (E) rats treated with vitamin $\mathrm{E}(10 \mathrm{mg} / \mathrm{kg}, n \mathrm{10})$; (F) rats treated with vitamin $\mathrm{E}(55 \mathrm{mg} / \mathrm{kg}, n 10)$.

The rats were killed by decapitation after 2 weeks of treatment. The colons were rinsed with saline $(9 \mathrm{~g}$ $\mathrm{NaCl} / \mathrm{l}$ ) and opened longitudinally; the mucosal layer was removed with the help of a glass slide and processed for DNA and RNA analysis, as described later.

The 8-OH-2'-deoxyguanosine (8-OHdG) levels in DNA in each experimental group were measured. The oxidative DNA damage using the comet assay in controls $(n 9)$ and in rats treated with 4-coumaric acid $(50 \mathrm{mg} / \mathrm{kg} ; n 10)$ and protocatechuic acid at the same dose $(n 6)$ were also analysed.

The expression of GSH-related enzymes of colonic mucosa harvested from control rats $(n 10)$, rats treated with protocatechuic acid $(50 \mathrm{mg} / \mathrm{kg} ; n$ 10) and rats treated with 4-coumaric acid $(50 \mathrm{mg} / \mathrm{kg} ; n$ 10) was investigated.

\section{Measurement of 8-OH-2'-deoxyguanosine levels in DNA}

After removing the mucosa layer (mainly made up of colonocytes but also including other types of cells such as endothelial cells), DNA was obtained as reported previously by Lodovici et al. (2000). Briefly, the mucosa was homogenized in the presence of cold $\mathrm{NaCl}$-sodium citrate $(0.15 \mathrm{M}, 0.015 \mathrm{M})$ and centrifuged at low speed. The pellets, after lysis with $5 \mathrm{ml}$ of buffer $(0.01 \mathrm{M}$-Tris-HCl, 0.01 M-EDTA; $0.01 \mathrm{M}-\mathrm{NaCl}, 0.5 \%$ (w/v) sodium dodecilsulfate $\mathrm{pH}$ 8), were incubated under $\mathrm{Ar}$ for $1 \mathrm{~h}$ at $37^{\circ} \mathrm{C}$ with $10 \mu \mathrm{g}$ RNAse. After incubation, $500 \mu \mathrm{g}$ proteinase K was added and the solution was incubated overnight at $37^{\circ} \mathrm{C}$, under Ar. DNA was then purified, denatured at

Table 1. Sequence of the oligonucleotide primers used for polymerase chain reaction amplification and the predicted product sizes

\begin{tabular}{|c|c|c|c|}
\hline Target & Primer forward & Primer reverse & Size \\
\hline $\begin{array}{l}\text { GST-P } \\
\text { GST-M1 } \\
\text { GST-M2 } \\
\text { GSPX1 } \\
\text { GSPX4 } \\
\gamma \text {-GCS } \\
\beta \text {-actin }\end{array}$ & $\begin{array}{l}\text { 5'-TGC CAC CGT ACA CCA TTG TGT-3' } \\
\text { 5'-GCT GAA GCC AAA TTG AGA AG-3' } \\
\text { 5'-CAG ACA CAA GCT ATG AGG AC-3' } \\
\text { 5'-CCA GAC GTT ATA CAG TAT GTC-3' } \\
\text { 5'-GTC TCA GCC GCT TAT TGA AGC CAG-3' } \\
\text { 5'-GCT GCA TCG CCA TTT TAC CGA G-3' } \\
\text { 5'-ACA CTG TGC CCA TCT ACG AGG-3' }\end{array}$ & $\begin{array}{l}\text { 5'-CAG CAG GTC CAG CAA GTT GTA-3' } \\
\text { 5'-ACC TCA AAT CAC AGA AAA GGA-3' } \\
\text { 5'-AAT GAA GAA ATG GAG AGA CC-3' } \\
\text { 5'-ATT CTT AGT GGT GAA CGC CAC-3' } \\
\text { 5'-CAC AAG GCA GCC AAG GTG AA-3' } \\
\text { 5'-TGG CAA CAG TCA TTA GTT CTC CA-3' } \\
\text { 5'-AGG GGC CGG ACT CGT CAT ACT-3' }\end{array}$ & $\begin{array}{l}479 \mathrm{bp} \\
938 \mathrm{bp} \\
768 \mathrm{bp} \\
805 \mathrm{bp} \\
777 \mathrm{bp} \\
862 \mathrm{bp} \\
621 \mathrm{bp}\end{array}$ \\
\hline
\end{tabular}

GST, glutathione-S-transferase; GSPX, glutathione peroxidase; $\gamma$-GCS, $\gamma$-glutamylcysteine. 
$90^{\circ} \mathrm{C}$ for $3 \mathrm{~min}$ and digested in a nucleoside pool using nuclease and alkaline phosphatase, under Ar. The 8-OHdG content was measured with HPLC coupled with electrochemical detection and 2-deoxyguanosine was u.v.-detected, following the established method (Lodovici et al. 2000). Oxidative damage was expressed as 8-OHdG:2-deoxyguanosine (Lodovici et al. 2000).

\section{Comet assay}

Basal oxidative DNA damage was also evaluated with the modified comet assay as described by Giovannelli et al. (2000). Colonic mucosa was rapidly dissected and nuclei were isolated by homogenisation in 20 vol. sucrose buffer. The homogenate $(20 \mu l)$ was mixed with $85 \mu l$ of low-melting-point agarose and run through the comet assay procedure as previously described (Giovannelli et al. 2000).

Damage was expressed as percentage migration of DNA in the tail and measured for each nucleus using a customized image analysis system. Each experimental point was run in duplicate, and a total of 100 nuclei were analysed for each rat. Oxidative DNA damage on pyrimidine bases was measured by subtracting the damage obtained after incubation with enzyme buffer only, from the damage obtained after incubation of the slides with the enzyme endonuclease III.

In order to prevent oxidative stress as an artifact in the measurement, both by the comet assay and by $8-\mathrm{OHdG}$ analysis, the European Standards Committee on Oxidative DNA Damage (2002) protocol was followed.

\section{Analysis of glutathione-related enzyme expression}

To prevent RNA degradation, colonic mucosa specimens were frozen immediately in liquid $\mathrm{N}_{2}$ and stored at $-80^{\circ} \mathrm{C}$ until analysis. Total RNA was isolated from rat colonic mucosa using the Trizol protocol as suggested by the supplier. The RNA quality was checked after electrophoresis on an agarose (1\%) gel stained with ethidium bromide; RNA was considered of an acceptable quality in the presence of two electrophoretic bands (28S and $18 \mathrm{~S}$ ), with no smearing of other bands or signals of DNA contamination. The purity was checked spectrophotometrically and accepted when specimens had an $\mathrm{A}_{260}: \mathrm{A}_{280}$ value comprised of between 1.8 and $2 \cdot 1$.

For first-strand cDNA synthesis, 200 ng RNA from each sample was reverse-transcribed using 100 units of reverse transcriptase superscript II and $1 \times$ random examers.

To amplify GST-P, GST-M2, GST-M1, $\gamma$-glutamylcysteine synthetase, GSPX1 and GSPX4 genes, primers were designed on the basis of the sequences reported by the UNIGENE database for the rat (Table 1).

Each gene was co-amplified together with $\beta$-actin as a control. For each gene the polymerase chain reaction (PCR) was carried out on samples of the cDNA preparation in a $25 \mu \mathrm{l}$ volume containing $1 \times \mathrm{PCR}$ buffer, $2 \mathrm{mM}-\mathrm{MgCl}_{2}$, $0.5 \mathrm{~mm}$-dNTPs, $8 \mathrm{ng} / \mu \mathrm{l}$ of each target gene primer, $0.2 \mathrm{ng} /$ $\mu l$ of the $\beta$-actin primers and 1.25 units of Taq polymerase. The PCR conditions were the same: $95^{\circ} \mathrm{C}$ for $7 \mathrm{~min}$ and then thirty cycles at $95^{\circ} \mathrm{C}$ for $30 \mathrm{~s}, 60^{\circ} \mathrm{C}$ for $30 \mathrm{~s}$ and $72^{\circ} \mathrm{C}$ for $55 \mathrm{~s}$ and a final extension at $72^{\circ} \mathrm{C}$ for $5 \mathrm{~min}$. To amplify GSPX4 an annealing temperature of $62^{\circ} \mathrm{C}$ was used.

The PCR products were separated on agarose (1.6\%) gel. The amplified products were photographed with a digital camera and the intensity of the bands was analysed with Quantity-One software (Bio-Rad, Segrate, Milan, Italy). For each target gene, the relative amount of mRNA in the samples was calculated using $\beta$-actin co-amplified as internal standard.

\section{Statistical analysis}

Data were analysed using the Statgraphic Statistical Package (Statistical Graphic Corporation, Rockville, MD, USA) and one-way ANOVA analysis.

\section{Results \\ Oxidative DNA damage}

Dietary treatments with phenolic acids at the dose administered had no observable effect on the animals' weight and general health.

The activity of protocatechuic acid and 4-coumaric acid on basal oxidative DNA damage was evaluated, measuring the $8-\mathrm{OHdG}$ levels in colonic mucosa DNA and by the comet assay.

Protocatechuic acid at the dose of $50 \mathrm{mg} / \mathrm{kg}$ did not significantly reduce oxidative DNA damage in rat colonic mucosa compared with controls, both by measuring the levels of 8 -OHdG (Fig. 1) and according to the comet assay (Fig. 2).

Treatment with 4-coumaric acid at the dose of $50 \mathrm{mg} / \mathrm{kg}$ strongly reduced (by about $50 \%$ ) basal oxidative DNA damage measured as 8 -OHdG levels $(P=0.002)$ and by the comet assay $(P=0 \cdot 019)$. However, 4-coumaric acid administered at $25 \mathrm{mg} / \mathrm{kg}$ did not reduce the $8-\mathrm{OHdG}$ levels in DNA of rat colonic mucosa compared with controls (Fig. 1).

The levels of 8-OHdG and oxidation damage measured with the comet assay were significantly correlated, as shown in Fig. 3 with data from controls and 4-coumaric acid $(50 \mathrm{mg} / \mathrm{kg})$-treated rats $(r 0.770 ; n 17 ; P=0.0002)$.

Surprisingly, vitamin E at the dose of $55 \mathrm{mg} / \mathrm{kg}$ induced a significant increase in the basal oxidative DNA damage in rat colonic mucosa $(P=0.0092)$; at the dose of $10 \mathrm{mg} / \mathrm{kg}$ this vitamin did not have a significant effect (Fig. 1).

\section{Expression of glutathione-related enzymes}

In order to study possible mechanisms through which protocatechuic acid and 4-coumaric acid might decrease oxidative DNA damage, the mRNA levels of several GSH-related enzymes (GST-P, GST-M2, GST-M1, $\gamma$-glutamylcysteine synthetase, GSPX1 and GSPX4) were analysed in colonic mucosa.

As shown in Fig. 4, dietary treatment with $50 \mathrm{mg}$ of 4-coumaric acid $/ \mathrm{kg}$ significantly induced the expression of GST-M2 $(P=0.041)$, but did not change the expression 


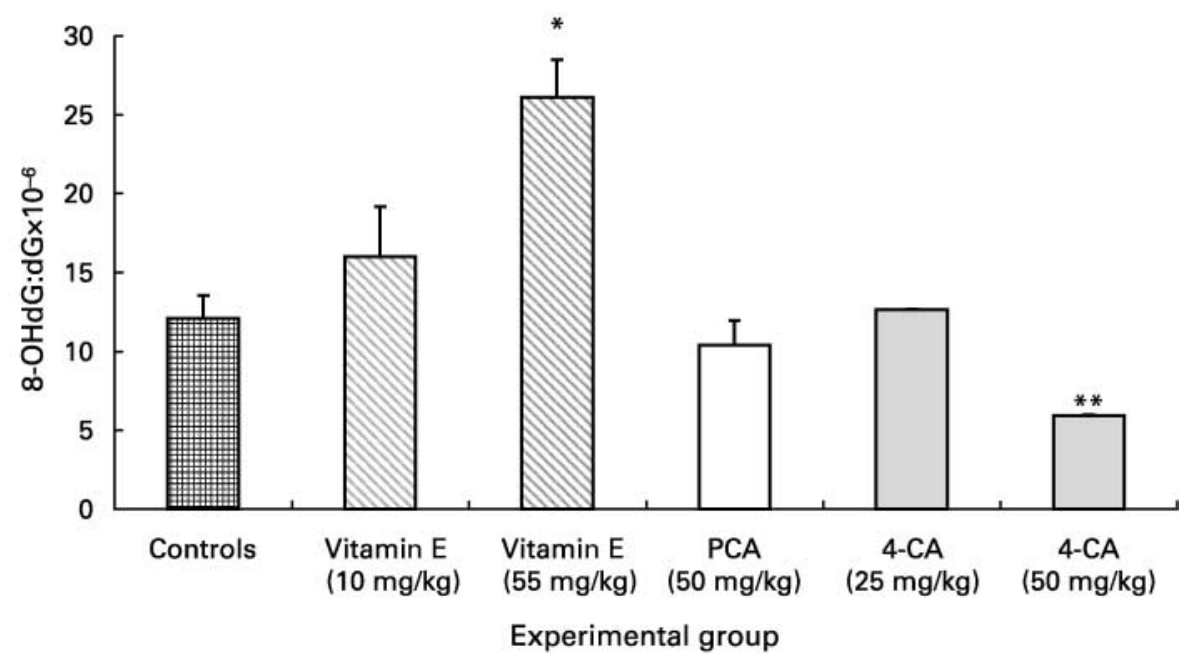

Fig. 1. Effect of vitamin E, and protocatechuic acid (PCA) and 4-coumaric acid (4-CA) on the basal levels of 8-OH-2'-deoxyguanosine $(8-\mathrm{OHdG})$ in rat colonic mucosa. Control values were obtained by measuring 8-OHdG in DNA of the colonic mucosa in rats fed standard laboratory chow. Mean values for ten rats are shown, with standard errors of the mean being represented by vertical bars. Mean value was significantly different from that of the control group. ${ }^{*} P=0.0092,{ }^{\star \star} P=0.002$, dG, deoxyguanosine.

of the other enzymes significantly. Some of these, such as GSPX1 and GSPX4 (isoforms of glutathione peroxidases), have a very low expression in the colon (data not shown).

Protocatechuic acid had no effect on GSH-related enzymes.

\section{Discussion}

There are several studies of the activity of protocatechuic acid, a simple phenolic compound present in several types of foods, on hydroxyl radicals (Tseng et al. 1996; Ueda et al. 1996; Masella et al. 1999) and LDL oxidation (Laranjinha et al. 1994). It was previously demonstrated that the protective effect of protocatechuic acid on $\mathrm{Fe}$ induced oxidative DNA damage in vitro may be attributed to its Fe affinity (Jacobs et al. 1977; Lodovici et al. 2001). In the present study animals treated with protocatechuic acid $(50 \mathrm{mg} / \mathrm{kg})$ showed a slight and non-significant reduction of basal oxidative DNA damage and no variation in GSH-related enzymes. It is possible that a significant protective effect of this polyphenol could be found using vitamin E-depleted animals as reported by Ramirez-Tortosa et al. (2001) for similar compounds, since the normal dose of vitamin E might have masked in the present experiment its potential antioxidant power, demonstrated in vitro (Lodovici et al. 2001). In contrast, 4-coumaric acid, a phenolic acid present in many common foods and drinks, such as wine, tea, spinach, Brussels sprouts, cereals, apples and berries (Stich, 1991; Clifford, 2000), was able to reduce basal oxidative DNA damage in rat colonic mucosa.

In the existing literature data the dietary burden of 4coumaric acid and protocatechuic acid is not precisely known, although dietary intake of total cinnamates and

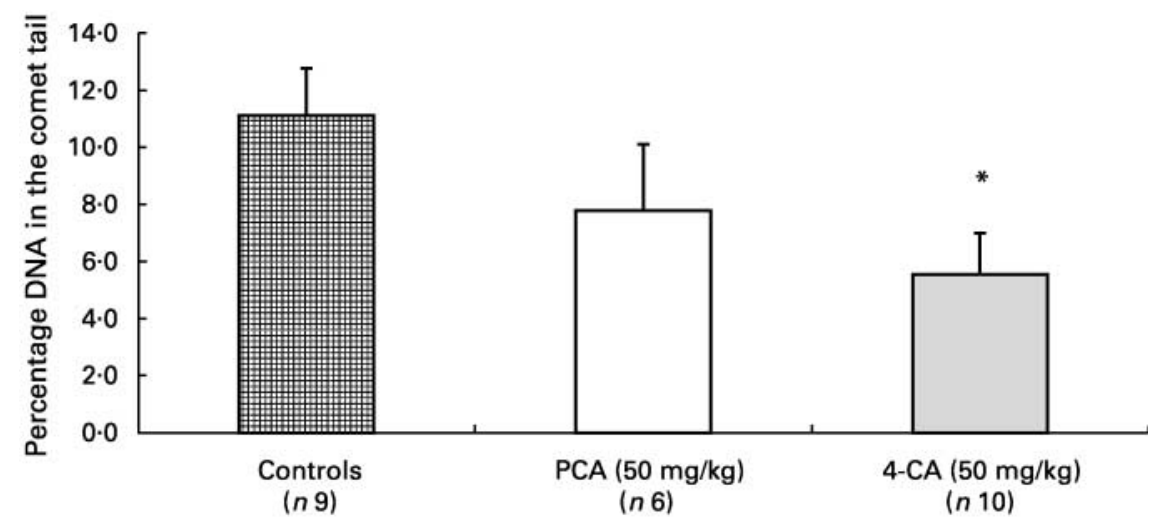

Experimental group

Fig. 2. Effect of protocatechuic acid (PCA) and 4-coumaric acid (4-CA) on the DNA oxidative damage in rat colonic mucosa nuclei measured with the comet assay. Data are expressed as mean values of percentage DNA migrated in the comet tail, with standard errors of the mean being represented by vertical bars. Specific oxidative damage on pyrimidine bases was calculated by subtracting the damage obtained after incubation with buffer (background breaks) from the damage obtained after incubation with endonuclease III (background breaks+breaks in endonuclease III-sensitive sites). Mean value was significantly different from that of the control group, ${ }^{\star} P=0.019$. 


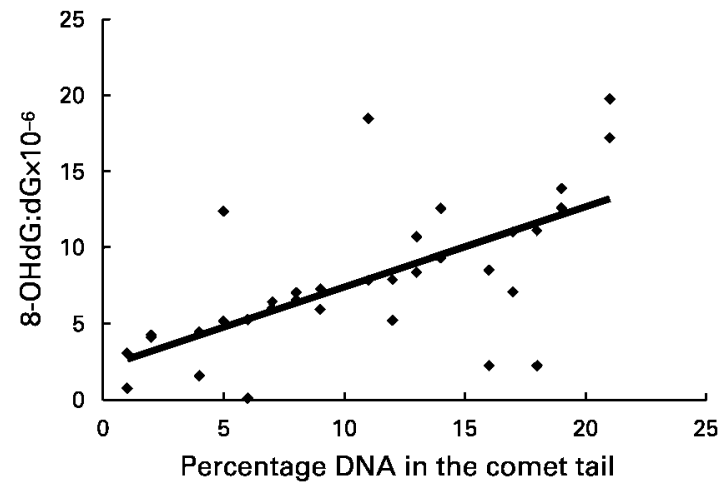

Fig. 3. Correlation between $8-\mathrm{OH}-2^{\prime}$-deoxyguanosine (8-OHdG) levels in DNA and DNA damage measured with the comet assay in controls and rats treated with 4-coumaric acid at the dose of $50 \mathrm{mg} / \mathrm{kg}(r 0.770, n 17, P<0.0002) . \mathrm{dG}$, deoxyguanosine.

hydroxybenzoic derivatives has been estimated to be up to 1 g/d (Clifford, 2000; Tomàs-Barberan \& Clifford, 2000). Therefore the effects described in the present paper are of particular interest since they were observed at doses comparable to possible human dietary intake.

Previous studies reported that 4-coumaric acid is a potent inhibitor of LDL oxidation in vitro (Satué-Gracia et al. 1999; Morton et al. 2000). Owen et al. (2000) also found that 4-coumaric acid possesses antioxidant activity against reactive oxygen species produced by hypoxanthine and xanthine oxidase; moreover, anti-mutagenic activity of this phenolic acid was reported in the Salmonellamicrosomes assay (Eaton \& Bammler, 1999).

Recently it was reported that 4-coumaric acid reduced oxidative DNA damage induced in vitro by $\mathrm{Fe}$ and cumene hydroperoxide (Lodovici et al. 2001). The present in vivo experiments showed that 4-coumaric acid decreases effectively oxidative DNA damage in rat colonic mucosa. This effect might be explained by the increased expression of GST-M2, an important isoform of GST, which is highly expressed in many tissues (Eaton \& Bammler, 1999) and plays a protective role against endogenous oxidative stress in many tissues (Baez et al. 1997). It is interesting to observe in this respect that epigallocatechin gallate, one of the major constituents of green tea polyphenols with interesting chemopreventive activities, specifically induces the GST-M2 isoform (Chou et al. 2000).

An interesting, although unexpected, outcome of our work was the observation that vitamin $E$ at relatively high doses $(55 \mathrm{mg} / \mathrm{kg})$ enhances oxidative stress in colonic mucosa; at the dose of $10 \mathrm{mg} / \mathrm{kg}$ no effect was observed. Vitamin $\mathrm{E}$ is essential for cellular stability: it efficiently scavenges free radicals (Rimm et al. 1993), protects against some types of cancers (Knekt et al. 1991) and increases the kinetics of repair of radiation-induced DNA damage in the mouse (Konopacka et al. 1998). However, in some studies vitamin $\mathrm{E}$ has also been shown to have tumour-promoting activity (Mitchel \& McCann, 1993; Burkitt \& Milne, 1996), possibly inducing some metabolic activation enzymes (Lii et al. 1998).

Absorption, distribution, metabolism and elimination of 4-coumaric acid and protocatechuic acid have not been yet extensively investigated. Since these two dietary compounds are acids, they are probably absorbed mainly in the stomach and in the first part of intestine, as reported for other similar compounds (Fahelbum \& James, 1977). It is possible that 4-coumaric acid and protocatechuic acid as such or as conjugated with glycine or glucuronic acid are excreted through the gut, where they can be deconjugated and hydroxylated by the gut flora, as reported for similar cinnamic and benzoic acids (Clifford, 2000; Tomàs-Barberan \& Clifford, 2000). The final effect, seen in colonic mucosa by feeding rats with these dietary phenolic acids, may be principally due via the circulation (by decreasing oxygen radicals or inducing GSH-related enzymes), without excluding a possible luminal effect of some of their metabolites.

In conclusion, our data suggest that 4-coumaric acid, a common constituent of some human diets, can reduce basal DNA oxidative damage and induce some GSH-related

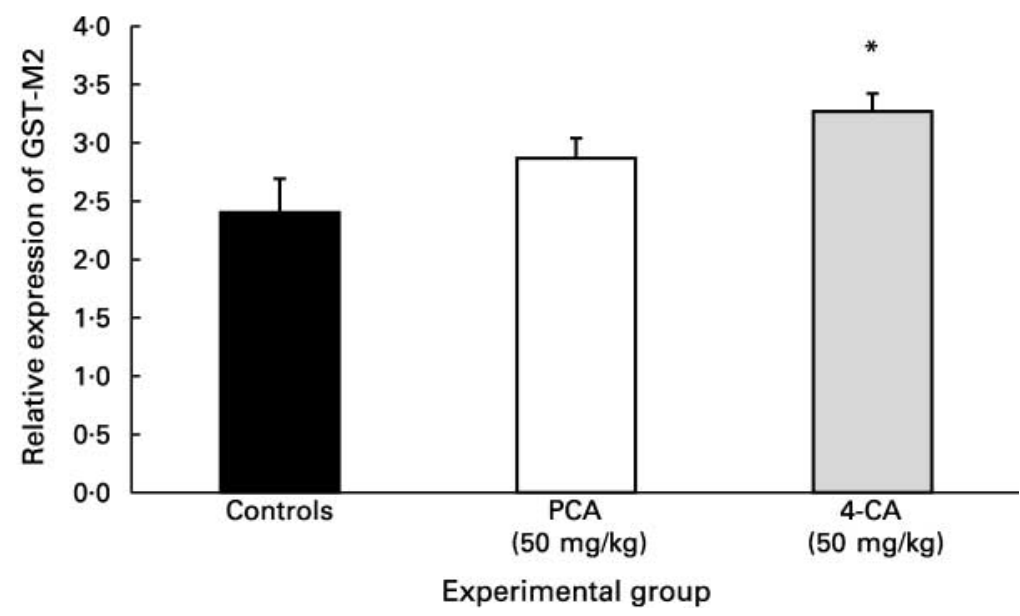

Fig. 4. Relative expression of glutathione-S-transferase (GST) M2 in the colonic mucosa of rats treated with protocatechuic acid (PCA) and 4 -coumaric acid (4-CA). For each target gene, the relative amount of mRNA in the samples was calculated using co-amplified $\beta$-actin. Data are expressed as mean values for ten rats per group, with standard errors of the mean being represented by vertical bars. Mean value was significantly different from that of the control group, ${ }^{*} P=0.041$. 
enzymes. These mechanisms may explain the association between high consumption of fruits and vegetables, rich in phenolic acids, and the inhibition of disease processes related to oxidative stress (Hertog, 1995).

\section{Acknowledgements}

This study was supported by a grant from the European Community (POLYBIND, QLRT-1999-00505) and by funds of MURST, Italy.

\section{References}

Baez S, Segura-Aguilar J, Widersten M, Johasson AS \& Mannervik B (1997) Glutathione transferases catalyse the detoxication of oxidized metabolites (o-quinones) of catecholamines and may serve as an antioxidant system preventing degenerative cellular process. Biochemical Journal 324, 25-28.

Brown JP (1980) A review of the genetic effects of naturally occurring flavonoids, anthraquinones and related compounds. Mutation Research 75, 243-277.

Burkitt MJ \& Milne L (1996) Hydroxyl radical formation from $\mathrm{Cu}$ (II)-trolox mixture insights into the pro-oxidant properties of $\alpha$-tocopherol. FEBS Letters 379, 51-54.

Caderni G, De Filippo C, Luceri C, Salvadori M, Giannini A, Biggeri A, Remy S, Cheynier V \& Dolara P (2000) Effects of black tea, green tea and wine extracts on intestinal carcinogenesis induced by azoxymethane (AOM) in F344 rats. Carcinogenesis 21, 1965-1969.

Chou FP, Chu YC, Hsu JD, Chiang HC \& Wang CJ (2000) Specific induction of glutathione S-transferase GSTM2 subunit expression by epigallocatechin gallate in rat liver. Biochemical Pharmacology 6, 643-650.

Clifford MN (2000) Chlorogenic acids and other cinnamates nature, occurrence, dietary burden, absorption and metabolism. Journal of Science and Food Agriculture 80, 1033-1043.

Eaton DL \& Bammler TK (1999) Concise review of the glutathione S-Transferases and their significance to Toxicology. Toxicological Science 49, 156-164.

European Community (1986) European Community Regulations on the Care and Use of Laboratory Animals, Law 86/609/EC.

European Standards Committee on Oxidative DNA Damage (2002) Comparative analysis of baseline 8-oxo-7,8-dihydroguanine in mammalian cell DNA, by different methods in different laboratories: an approach to consensus. Carcinogenesis 23, 2129-2133.

Fahelbum IM \& James SP (1977) The absorption and metabolism of methyl cinnamate. Toxicology 7, 123-132.

Fiander H \& Schneider H (2000) Dietary ortho phenols that induce glutathione $\mathrm{S}$-transferase and increase the resistance of cells to hydrogen peroxide are potential cancer chemopreventives that act by two mechanisms: the alleviation of oxidative stress and the detoxification of mutagenic xenobiotics. Cancer Letters 156, 117-124.

Giovannelli L, Testa G, De Filippo C, Cheynier V, Clifford MN \& Dolara P (2000) Effect of complex polyphenols and tannins from red wine on DNA oxidative damage of rat colon mucosa in vivo. European Journal of Nutrition 39, 207-212.

Havsteen B (1983) Flavonoids, a class of natural products of high pharmacological potency. Biochemical Pharmacology 32, $1141-1149$.

Hertog MGL (1995) Flavonoid intake and long term risk of coronary heart disease and cancer in the 7 countries study. Archives of Internal Medicine 155, 1184-1195.
Hertog MGL, Fesken EJM, Hollman PCH, Katan MB \& Kromhout D (1993) Dietary antioxidant flavonoids and risk of coronary artery disease, the Zutphen Elderly Study. Lancet 342, 1007-1011.

Jacobs A, White GP \& Tait GP (1977) Iron chelation in cell cultures by two conjugates of 2,3-dihydroxybenzoic acid (2,3-DHB). Biochemical and Biophysical Research Communications 74, 1626-1630.

Knekt P, Aromaa A, Maatela J, Aaran RK, Nikkau T, Hakama M, Hakulinen T, Peto R \& Teppo L (1991) Vitamin E and cancer prevention. American Journal of Clinical Nutrition 53, 283-286.

Konopacka M, Widel M \& Rzeszowska-Wolny J (1998) Modifying effect of Vitamin C, E and beta-carotene against gamma-ray induced DNA damage in mouse cells. Mutation Research 417, 85-94.

Laranjinha JA, Almeida LM \& Madeira VM (1994) Reactivity of dietary phenolic acids with peroxyl radicals: antioxidant activity upon low density lipoprotein peroxidation. Biochemical Pharmacology 48, 487-494.

Lii CK, Sung WC, Ko YJ \& Chen HW (1998) Alpha-Tocopherol acetate supplementation enhances rat hepatic cytochrome PROD activity in the presence of Phenobarbital induction. Nutrition and Cancer 32, 37-42.

Lodovici M, Casalini C, De Filippo C, Copeland E, Xu X, Clifford M \& Dolara P (2000) Inhibition of 1,2-dimethylhydrazine-induced oxidative DNA damage in rat colon mucosa by black tea complex polyphenols. Food and Chemical Toxicology 38, 1085-1088.

Lodovici M, Guglielmi F, Meoni M \& Dolara P (2001) Effect of natural phenolic acids on DNA oxidation in vitro. Food and Chemical Toxicology 39, 1205-1210.

Masella R, Cantafora A, Modesti D, Cardilli A, Gennaro L, Bocca A \& Coni E (1999) Antioxidant activity of 3,4-DHPEA-EA and protocatechuic acid: a comparative assessment with other olive oil biophenols. Redox Reports 4, 113-121.

Mitchel REJ \& McCann R (1993) Vitamin E is a complete tumour promoter in mouse skin. Carcinogenesis 14, 659-662.

Morton LW, Croft KD, Puddey IB \& Byrne L (2000) Phenolic acids protect low density lipoproteins from peroxynitrite-mediated modification in vitro. Redox Reports 5, 124-125.

Owen RW, Giacosa A, Hull WE, Haubner R, Spiegelhalder B \& Bartsch H (2000) The antioxidant/anticancer potential of phenolic compounds isolated from olive oil. European Journal of Cancer 36, 1235-1247.

Ramirez-Tortosa C, Andersen OM, Gardner PT, Morrice PC, Wood SG, Duthie SJ, Collins AR \& Duthie GG (2001) Anthocyanin-rich extract decreases indices of lipid peroxidation and DNA damage in vitamin E-depleted rats. Free Radical Biology and Medicine 1, 1033-1037.

Rimm EB, Ascherio A, Giovannucci E, Spiegelman D, Stampfer MJ \& Willett WC (1996) Vegetable, fruit, and cereal fiber intake and risk of coronary heart disease among men. Journal of the American Medical Association 275, 447-451.

Rimm EB, Stampfer MJ, Ascherio A, Giovannucci E, Colditz GA \& Willet WC (1993) Vitamin E consumption and the risk of coronary heart disease in men. New England Journal of Medicine 328, 1450-1456.

Satué-Gracia MT, Andrés-Lacueva C, Lamuela-Raventós RM \& Frankel EN (1999) Inhibitors of in Vitro Human Low-Density Lipoprotein Oxidation. Journal of Agriculture and Food Chemistry 47, 2198-2202.

Steel VE, Kelloff GJ, Balentine D, Boone CW, Mehta R, Bagheri D, Sigman CC, Zhu S \& Sharma SVE (2000) Comparative chemopreventive mechanisms of green tea, black tea and selected polyphenol extracts measured by in vitro bioassays. Carcinogenesis 21, 63-67. 
Stich HF (1991) The beneficial and hazardous effects of simple phenolic compounds. Mutation Research 259, 307-324.

Stich HF, Ohshima H, Pignatelli B, Michelon J \& Bartsch H (1983) Inhibitory effect of betel nut extracts on endogenous nitrosation in humans. Journal of the National Cancer Institute 70, $1047-1050$.

Tomàs-Barberan FA \& Clifford MN (2000) Dietary hydroxibenzoic acid derivatives - nature, occurrence and dietary burden. Journal of Science and Food Agriculture 80, 1024-1032.
Tseng TH, Wang CJ, Kao ES \& Chu HY (1996) Hibiscus protocatechuic acid protects against oxidative damage induced by tert-butylhydroperoxide in rat primary hepatocytes. Chemical Biological Interaction 101, 137-148.

Ueda J, Saito N, Shimazu Y \& Ozawa TA (1996) Comparison of scavenging abilities of antioxidant against hydroxyl radicals. Archives of Biochemistry and Biophysics 333, $377-383$.

Willet WC (2000) Diet and cancer. Oncologist 5, 393-404. 